\title{
Hellere i Rogaland og bruken av landskapet i førromersk jernalder
}

\section{Innledning}

Formålet med denne artikkelen er å diskutere hvordan hellere i Rogaland ble anvendt i førromersk jernalder, og hvilken rolle de har spilt i utnyttelsen av landskapet. Utgangspunktet for diskusjonen er en heller ved navn Helleren, i Jøssingfjord, som ligger helt sørvest i Sokndal kommune (figur 1).

De første arkeologiske undersøkelsene i Helleren ble gjort i 1964 (Myhre 1964a, 1964b). Da ble det gravd to prøvestikk, hvor det ble påvist et ca. $60 \mathrm{~cm}$ tykt kulturlag med mye trekull. I laget fantes det en del bein, store mengder skjell og et avslag av flint. Det ble også funnet en del flintavslag i overflaten. I flere omganger etter denne undersøkelsen er det samlet opp steinartefakter fra Helleren, bl.a. en skiferspiss som kan dateres til tidlig yngre steinalder. Med bakgrunn i disse funnene har en antatt at kulturlaget i Helleren hovedsakelig er avsatt i løpet av steinalderen (Myhre 1964b; Haraldsen 1982; Storvik 2011). Imidlertid viser nye undersøkelser, gjennomført i 2016, at store deler av laget skal dateres til førromersk jernalder (Meling 2016a).

I tid faller dateringen sammen med en tydelig ekspansjon i bosetningen på Vestlandet, der etablerte jordbruksområder ble utvidet og nye ble ryddet (bl.a. Diinhoff 2005a, 2005b; Løken mfl. 1996, Løken 1998; Myhre 2002). Vegetasjonshistoriske undersøkelser viser et lignende bilde, og langs kysten av Rogaland ble gress- og lynghei den dominerende landskapstypen i løpet av perioden (Prøsch-Danielsen og Simonsen 2000). Denne ekspansjonen danner bakteppe for diskusjonen omkring hellerne i Rogaland. Jeg vil argumentere for at bruken var underlagt kollektive avgjørelser og bestemmelser, på lik linje med fordelingen av jord og adgangen til å etablere gårder i denne perioden (jf. Friman 2008; Gerritsen 1999; Herschend 2009). Aktivitetene i Helleren ser ut til å ha vært rettet mot en felles utnyttelse av marine ressurser, mens de andre, som har ligget i beitelandskap, blir relatert til økt behov for å markere rettigheter i den gårdsnære utmarka. 


\section{Huler og hellere i jernalderen - en kort forskningshistorie}

Bruken av huler og hellere i jernalderen har vært et forskningstema i Norge siden midten av 1800-tallet (Bergsvik 2005). Det har vært flere teorier om hvem som benyttet dem, og hvorfor, men frem til slutten av 1960-tallet var mange av spørsmålene sentrert omkring kulturdualisme i Sør-Norge (Bergsvik 2005:237-245; Dommasnes 2006:70-71). Flere tok bl.a. til orde for at hellerne ble benyttet av en befolkning som hovedsakelig levde av jakt og fangst, og som fremstod som mer «primitiv» enn den germanske bondebefolkningen (bl.a. Gjessing 1945; Hagen 1967). Samtidig pekte andre på at funnmaterialet fra hellerne ikke skilte seg nevneverdig ut fra det på jordbruksboplassene, og at det derfor var mer sannsynlig at bøndene hadde anvendt hellerne i forbindelse med jakt/fangst, setring og andre sesongaktiviteter (bl.a. Bakka 1973; Brøgger 1925; Solberg 1976). Hulene og hellerne var med andre ord ikke et uttrykk for ulike etniske grupper i jernalderen (Bakka 1973). Enkelte mente likevel at de kunne ha fungert som helårsboplasser for en ervervsmessig spesialisert befolkning (Jansen 1973; Odner 1973). Knut Odner (1973) satte hellerne i sammenheng med fremveksten av et mer stratifisert samfunn i løpet av romertiden, og mente at de som holdt til i dem, var underlagt høvdingene i de gode jordbruksbygdene, og at de utnyttet utmarksressursene på oppdrag fra dem.

Det er ingen arbeider som har behandlet det førromerske hellermaterialet spesifikt, men de siste årene har materialet fra perioden inngått i flere regionale studier som omhandler vestnorske hellere (bl.a. Bommen 2009; Hufthammer 2015; Storvik 2011; Østebø 2008). Problemstillingene i disse studiene varierer, men samtlige mener at de ble benyttet av en jordbrukende befolkning i jernalderen. Både lokaliseringene i landskapet og det arkeologiske materialet viser at hellerne har hatt varierende funksjoner (Storvik 2011:83; Østebø 2008:78), men generelt fremstår de ulike aktivitetene som periodiske og sesongbetonte. Selv om førromersk jernalder trolig er underrepresentert i det arkeologiske materialet (Østebø 2008:61-62), viser både funnmengden og lagtykkelsen at flere hellere ble benyttet mer intensivt i romertid og folkevandringstid enn i tiden før vår tidsregning (Bommen 2009:87). I en del hellere ser det også ut til at aktivitetene var mer rettet mot jakt og fangst i førromersk jernalder enn i romertid og folkevandringstid (Bommen 2009:76).

\section{Samfunnet i forromersk jernalder}

Samfunnet i førromersk jernalder blir gjerne oppfattet som relativt egalitært. Det skyldes bl.a. at det er forholdsvis få gravfunn fra perioden, og de som finnes, fremstår som enkle branngraver uten statusmarkører og med få eller ingen gjenstander (Solberg 2000:65). Gravskikken representerer imidlertid ikke noe brudd med forholdene i yngre bronsealder, og på flere gravfelt er det en tydelig kontinuitet mellom de to periodene, både når det gjelder behandlingen av de døde og gravenes oppbygning og utforming (Dommasnes 1997, 2001; Rødsrud 2008). Enkelte steder er det påvist en romlig nærhet mellom grav og boplass i førromersk jernalder (bl.a. Meling 2008), men generelt ser det ikke ut til å være noen klar sammenheng mellom utbredelsen av gravene og lokaliseringen av gårdsbosetningen i denne perioden (Dommasnes 1997; Pilø 1989). Det enkle og til dels enhetlige uttrykket i gravene kommer best frem på gravfeltene, hvor mange av røysene fremstår som funntomme og uten spor etter den avdøde (bl.a. Dommasnes 1997, 2001). Individuelle trekk er så å si fraværende i gravene, og sannsynligvis representerer gravfeltene en kollektiv arena der ritualene og 


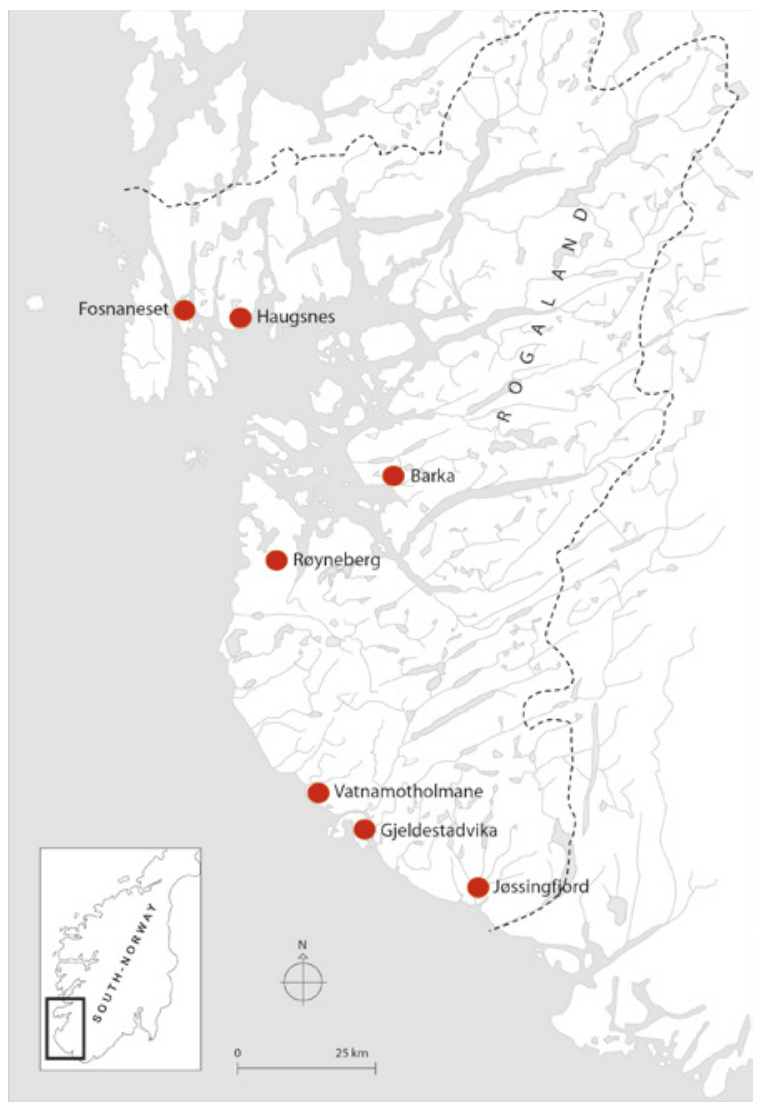

Figur 1. Den geografiske utbredelsen av hellere i Rogaland med dateringer til førromersk jernalder. Illustrasjon: Trond Meling, Arkeologisk museum, Universitetet i Stavanger.

seremoniene rundt begravelsene var et samlende element og et felles anliggende (Dommasnes 2001:117-118; Solevåg 2002:9698). Det uniforme finner vi også igjen i den førromerske gårdsbosetningen ved at den fremstår som ensartet både i utforming og størrelse. På Vestlandet ser vi noen regionale forskjeller i byggemåte (Diinhoff 2005a), men ut over det viser langhusene flere fellestrekk ved at de har en lengde på rundt 15 m og en oppdeling i bolig- og økonomidel (Diinhoff 2005a, 2005b; Løken 1998; Myhre 2002). Som regel er det bare én bygning på gårdene, men i noen tilfeller er det også funnet en tilhørende verkstedbygning (Diinhoff 2005a). Åkrene har ligget tett ved husene, og flere steder er det funnet mektige åkerlag som vitner om intensiv dyrking og en forholdsvis stabil bosetning (Diinhoff 1999, 2005c; Myhre 2002).

Den rådende oppfatning er at gårdene var bebodd av et familielignende hushold, og at rettighetene til bl.a. jord hang nøye sammen med hvor lenge hvert enkelt hushold bestod som en enhet (Bukkemoen 2015:113; Gerritsen 1999:143-144; Herschend 2009:169-170). Dersom sammensetningen av husholdet ble endret, bl.a. ved dødsfall eller ekteskap, måtte rettighetene knyttet til gårdene reforhandles (Herschend 2009:170). En konsekvens av det var at nye gårder ble ryddet og etablert, og at de eksisterende stadig måtte «gjenoppstå» ved at husene ble skiftet ut. Den sterke bosetningsekspansjonen som en ser på Vestlandet fra slutten av yngre bronsealder og utover i førromersk jernalder, kan forklares ut fra dette systemet. En del steder, særlig i gode jordbruksstrøk, ser en også at gårdene ble relokalisert gjentatte ganger innenfor et begrenset område (Diinhoff 2005a). I mer marginale jordbruksområder derimot, har gårdene gjerne kun en eller to faser (Meling 2008). 
I det arkeologiske materialet fra perioden finnes det også trekk som indikerer at deler av befolkningen på Vestlandet hadde større fokus på husdyrhold og fangst, og at de etablerte seg på mer perifere steder langs kysten (Bergsvik 2006). Det er foreslått at denne befolkningen har hatt begrensede muligheter til å akkumulere et overskudd som kunne overføres til neste generasjon. Derfor har de over tid kommet i et underordnet forhold til befolkningen i de gode jordbruksområdene (Bergsvik 2006:127). Mot slutten av førromersk jernalder ser en også kimen til økt stratifisering i samfunnet, ved at det ble etablert enkelte større gårdsenheter med lengre og mer komplekse bygninger (Grønnesby 1999; Løken 2001). Det er også eksempler på at husene fikk en mer permanent karakter i slutten av perioden. Trolig skyldes dette at husholdene fikk sterkere rettigheter til gårder og jord (Bukkemoen 2015).

Bosetningsmønsteret i førromersk jernalder har påvirket hvordan landskapet rundt gårdene ble utnyttet. Utmarka var en viktig ressurs og sannsynligvis var det knyttet både rettigheter og restriksjoner til utnyttelsen av disse ressursene. Hellerne, som ofte ligger sentralt til i den gårdsnære utmarka, var trolig viktige steder både for selve bruken av utmarka, men også for organiseringen av rettigheter i landskapet.

\section{Helleren i Jøssingfjord}

Helleren ligger sørvendt til innerst og på nordsiden av Jøssingfjord, i et forholdsvis trangt landskap preget av bratte og blankskurte fjellsider. Selve helleren er nærmere $100 \mathrm{~m}$ lang i retning nord-sør og rundt $20 \mathrm{~m}$ høy i dråpefallet. Fra de indre delene til dråpefallet er det ca.

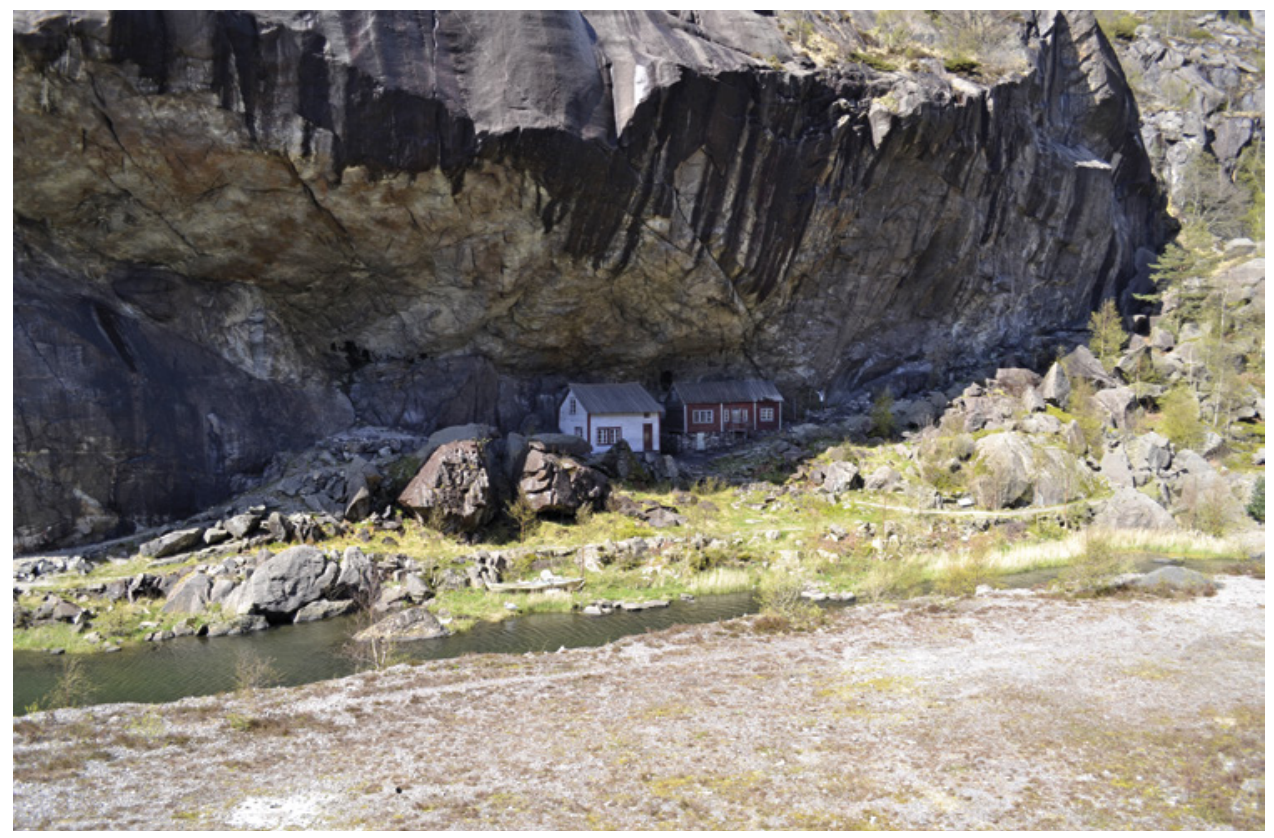

Figur 2. Helleren i Jøssingfjord har mektige dimensjoner. Kulturlaget ligger konsentrert mellom og under de to husene. Sett mot vest. Foto: Trond Meling, Arkeologisk museum, Universitetet i Stavanger. 
$15 \mathrm{~m}$ på det meste. Helleren ligger mellom 6 og $15 \mathrm{~m}$ over havet, og i overflaten er det flere steder eksponerte bergflater og store steinblokker (figur 2). Berggrunnen i denne delen av Sokndal består av anortositt, og det er et svært karrig landskap med lite løsmasser rundt Helleren (Dahl 1982). Under hellertaket står det to små hus fra første halvdel av 1800-tallet (figur 2). Beboerne var husmenn under gården Haneberg, som ligger på Hauge, ca. 3 km vest for Jøssingfjord (Hansteen 2014).

\section{Undersøkelsen i 1964}

Ved undersøkelsen i 1964 ble det gravd to prøvestikk (figur 3), og i begge var det et 50-60 cm tykt kulturlag (Myhre 1964a, 1964b). Rapporten fra undersøkelsen gir begrenset informasjon, men ut fra beskrivelsene ser det ut til at lagdelingen i prøvestikkene var forholdvis ensartet (Myhre 1964a). Den øverste delen av kulturlaget var svært mørk med mye trekull, mens nivåene under skilte seg ut ved at de var iblandet en god del skjell. I den nedre delen fantes det blant annet et lag tettpakket med skjell. I hele kulturlaget ble det også funnet en god del bein, og nær bunnene ble det påvist et tynt lag med store mengder fiskebein.

\section{Undersøkelsene i 2016}

De arkeologiske undersøkelsene i 2016 hadde et begrenset omfang, og skyldes sikringstiltak $\mathrm{i}$ forbindelse med vedlikehold av husene (Meling 2016a, 2016b). Ved den første utgravingen ble det gravd to smale sjakter på hver side av grunnmuren til det nordligste huset (figur 3). Her fantes hovedsakelig påførte fyllmasser med gjenstander fra tiden etter at huset ble oppført (Meling 2016b), men det ble også påvist et mørkt, trekullholdig lag som er C14-datert til tidlig merovingertid (tabell 1). I tilknytning til dette laget ble det funnet noen små, brente beinfragmenter og en ubrent ryggvirvel av fisk.

Figur 3. Skisse som viser hvor de ulike undersøkelsene i Helleren er gjennomført. De røde sirklene angir prøvestikkene som ble gravd i 1964, mens prøverutene og sjaktene fra 2016 er markert med nummer. Illustrasjon: Trond Meling, Arkeologisk museum, Universitetet i Stavanger.
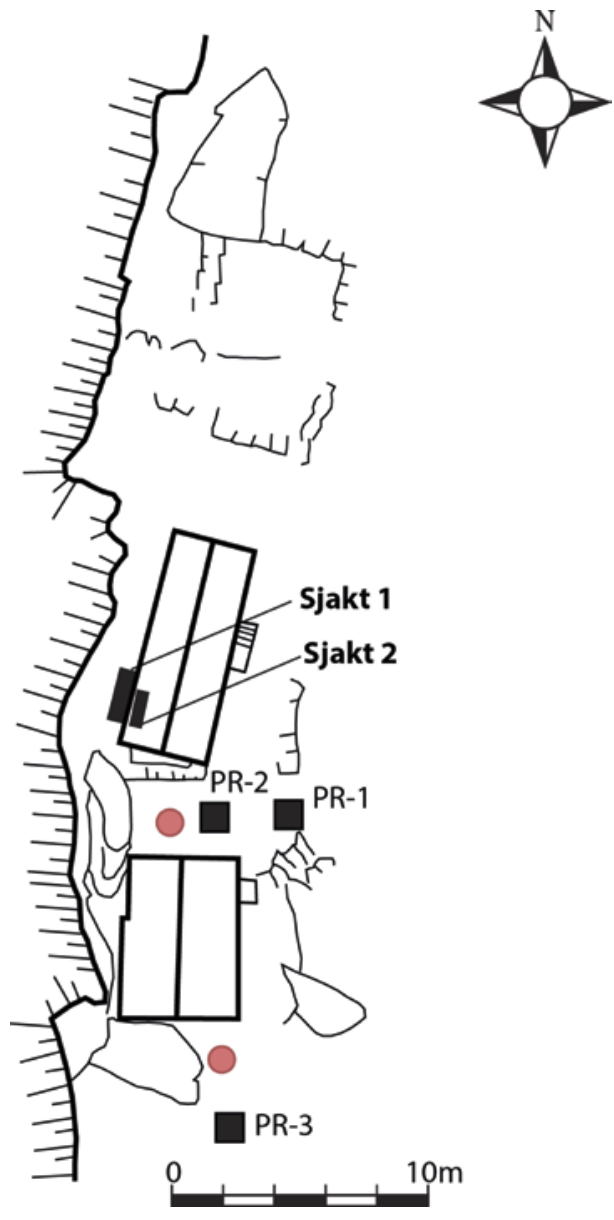


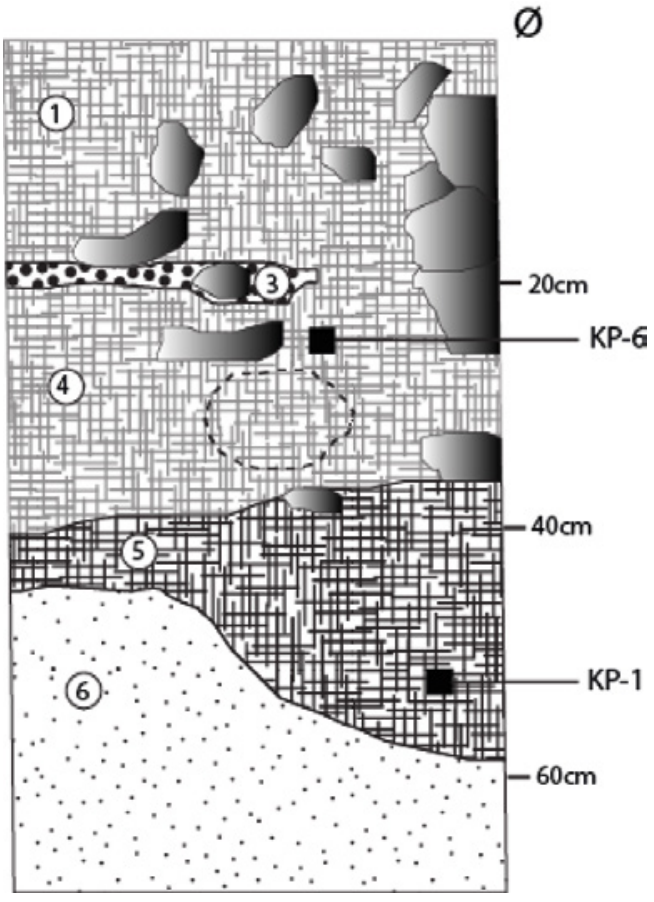

Figur 4. Den nordlige profilen i PR-2.

Tegning: Trond Meling.

Senere på året ble det gravd tre 50 x 50 $\mathrm{cm}$ store prøveruter under Helleren (figur 3). I en av dem (PR-2) ble det påvist kulturlag, mens det var ulike sand-/grusavsetninger i de to andre (Meling 2016a). Kulturlaget var $60 \mathrm{~cm}$ på det tykkeste. Det var relativt homogent fra øverst til nederst, men ut fra konsistensen og visuelle iakttagelser ble det skilt ut seks ulike faser i laget (figur 4). Lag 2 og lag 3, som lå henholdsvis ca. $10 \mathrm{~cm} \mathrm{og} 20-25 \mathrm{~cm}$ under overflaten, var to $3-5 \mathrm{~cm}$ tykke trekullinser, mens de andre lagene inneholdt en varierende mengde trekull og varmepåvirkede steiner. Det var færrest varmepåvirkede steiner $\mathrm{i}$ det nederste nivået (lag 5). Under kulturlaget fantes det lys, gulbrun sand (figur 4).

Det foreligger fire C14-dateringer fra kulturlaget (tabell 1). De viser at den nederste delen (lag 5) er fra slutten av eldre bronsealder, mens lagene over er avsatt i forromersk jernalder. Dateringene fra lag $1 \mathrm{~b}$ og lag 3 er sammenfallende, mens dateringen fra lag 4 er litt yngre. Prøven fra lag 4 ble tatt like under lag 3, men i et område hvor lag 3 ikke kunne følges i hele profilen (figur 4). Det er derfor mulig at denne delen av kulturlaget er noe for-

Tabell 1. C14-dateringer fra undersøkelsene i Helleren i 2016.

\begin{tabular}{|c|c|c|c|c|c|}
\hline Kontekst & Datert materiale & Lab.-ID & $\begin{array}{l}\text { Datering før } \\
\text { nåtid (BP) }\end{array}$ & $\begin{array}{l}\text { Kalibrert alder (68,3\% } \\
\text { sannsynlighet) }\end{array}$ & $\begin{array}{l}\text { Kalibret alder ( } 95,4 \% \\
\text { sannsynlighet) }\end{array}$ \\
\hline Sjakt 2- Lag 4 & $\begin{array}{l}\text { Hassel/Or (Corylus / } \\
\text { Alnus sp.) }\end{array}$ & UBA-32488 & $1434+36 \mathrm{BP}$ & 600-649 e.Kr. & 563-658 e.Kr. \\
\hline PR-2 - Lag 5 (KP-1) & $\begin{array}{l}\text { Bjørk/Rogn (Betula/ } \\
\text { Orbus) }\end{array}$ & Beta- 450828 & $3010+30 \mathrm{BP}$ & $\begin{array}{l}\text { 1260-1195 f.Kr./ 1140-1130 } \\
\text { f.Kr. }\end{array}$ & $\begin{array}{l}1365-1360 \text { f.Kr./1290-1120 } \\
\text { f.Kr }\end{array}$ \\
\hline PR-2 - Lag $3(K P-4)$ & Løvtre & Beta-450829 & $2190+30 \mathrm{BP}$ & 200-155 f.Kr./135-155 f.Kr. & $\begin{array}{l}345-320 \text { f.Kr./205-85 f. } \\
\text { Kr. } / 75-55 \text { f.Kr. }\end{array}$ \\
\hline PR-2 - $\operatorname{Lag} 4(K P-6)$ & Løvtre & Beta- 450930 & $2090+30 \mathrm{BP}$ & 155-135 f.Kr./ 115-45 f.Kr. & 170-20 f.Kr./10 f.Kr.-0 e.Kr. \\
\hline PR-2 - Lag 1b (KP-7) & Bjørk (Betula) & Beta-450931 & $2200+30 \mathrm{BP}$ & 355-285 f.Kr./230-200 f.Kr. & $360-170$ f.Kr. \\
\hline$P R-3-\operatorname{Lag} 2$ & Løvtre & Beta-450932 & $1560+30 \mathrm{BP}$ & 540-575 e.Kr. & $\begin{array}{l}\text { 430-490 e.Kr./510-515 e.Kr/ } \\
530-605 \text { e.Kr. }\end{array}$ \\
\hline
\end{tabular}


styrret og at prøven fra lag 4 kan være forurenset, og det igjen kan ha påvirket dateringsresultatet. Lag 2 ble ikke C14-datert, men ut fra stratigrafien og klare likheter med et trekullag i PR-3, som er datert til overgangen mellom folkevandringstid og merovingertid (tabell 1), er det nærliggende å tro at lag 2 i PR-2 er fra samme tid (Meling 2016a).

I sand- og gruslagene og i den nedre delen av kulturlaget fantes det enkelte flintartefakter. I tillegg ble det funnet et keramikkskår uten dekor i den øvre delen av kulturlaget (Meling 2016a). Det resterende funnmaterialet fra Helleren består av skjell og bein. Majoriteten av det kan relateres til kulturlaget, hvor det til sammen ble funnet $542 \mathrm{~g}$ skjell og $194 \mathrm{~g}$ bein. Blant skjellene er det blåskjell (Mytilus edulis) som dominerer, men i materialet finnes også fragmenter av oskjell (Modiolus modiolus), en del vanlig strandsnegl (Littorina littorina) og to biter av et albuskjell (Patellidea). Ingen av skjellene viser tegn til å være omformet eller benyttet som redskap eller anheng. Beinmaterialet fra Helleren er ikke undersøkt i detalj, men det aller meste ser ut til å være fra fisk og sjøpattedyr. Den vertikale fordelingen av bein og skjell i kulturlaget var forholdvis sammenfallende, og de fleste kan relateres til avsetningene som er datert til førromersk jernalder (figurene 5 og 6).

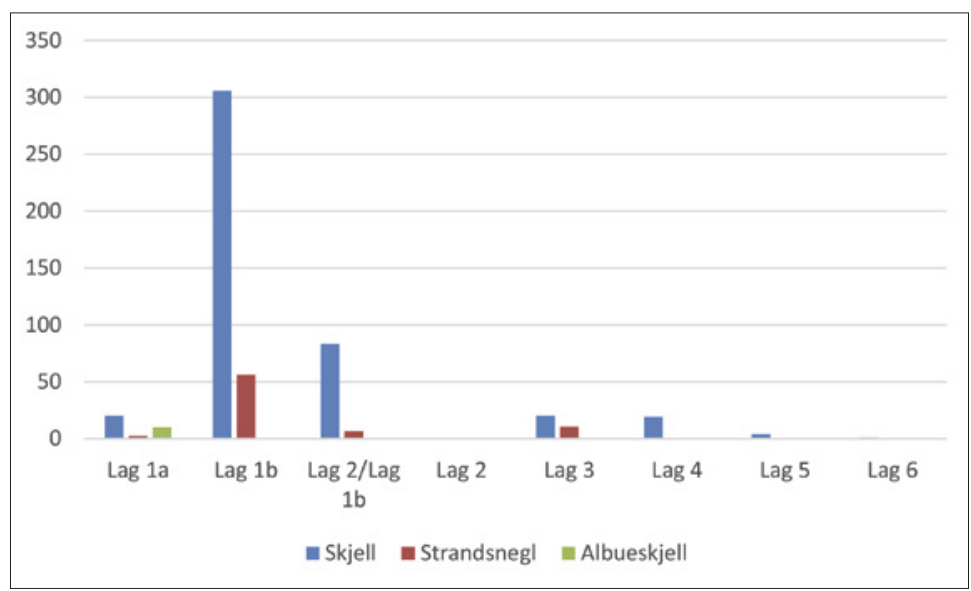

Figur 5. Diagram som viser mengden skjell (gram) $i$ PR-2. Illustrasjon: Trond Meling.

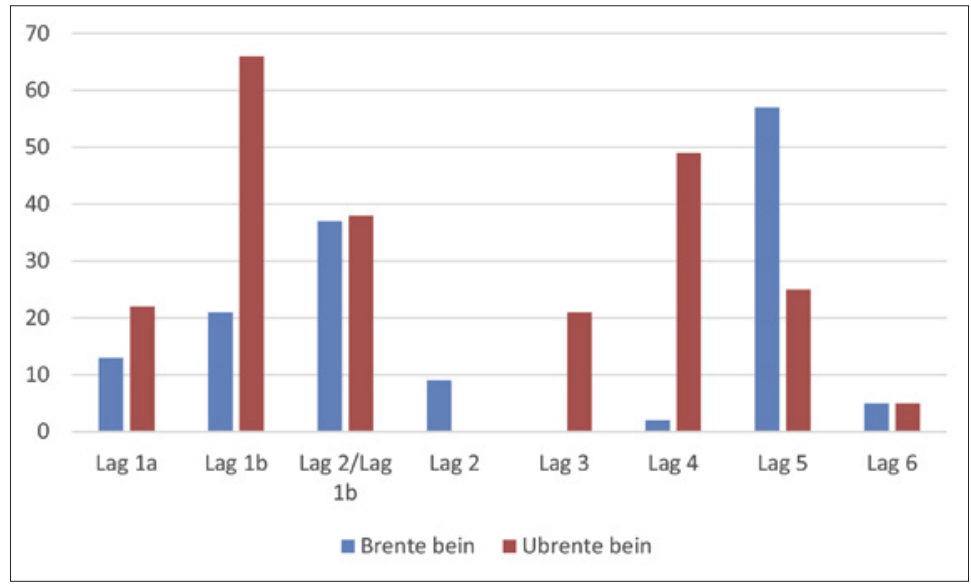

Figur 6. Diagram som viser mengden bein (antall) $i$ PR-2. Illustrasjon: Trond Meling. 


\section{Andre hellere i Rogaland med påvist bruk i førromersk jernalder}

I Rogaland er det registrert nær 100 huler og hellere med aktivitetsspor fra forhistorisk tid (Storvik 2011). De finnes i hele fylket, men det er en klar overvekt på Nord-Jæren og i kystområdene. Mange av hulene og hellerne har spor etter langvarig bruk. Det er flest med dateringer til steinalderen, men den mest intensive bruksfasen ser ut til å ha vært $\mathrm{i}$ eldre jernalder (Storvik 2011:31).

Det er kun et fåtall av hulene og hellerne som er undersøkt gjennom arkeologiske utgravinger. Dateringer ved hjelp av C14-metoden er også stort sett begrenset til dem som er nærmere undersøkt. Tidfestingen er derfor gjort ut fra gjenstandsfunn: hovedsakelig steinartefakter, keramikk eller metallgjenstander. Det er grunn til å tro at flere perioder er underrepresentert i materialet, bl.a. førromersk jernalder, siden en god del av funnmaterialet ikke kan dateres nærmere typologisk (jf. Østebø 2008:61-62). Foruten Helleren i Jøssingfjord er det seks hellere i Rogaland som har dateringer til førromersk jernalder (figur 1). Samtlige ligger i lavlandet og nær kysten. Alle er også undersøkt arkeologisk, og aktiviteten i førromersk jernalder er først og fremst tidfestet gjennom C14-dateringer av lag og strukturer.

\section{Gjeldestadvika i Eigersund kommune}

I 1971 ble det undersøkt en liten heller ved Gjeldestadvika på østsiden av Eigerøy i Eigersund kommune (figur 1). Den lå tett ved sjøen, ca. 10 m over havet, i et småkupert landskap med flere nakne fjellknauser og begrensede løsmasseavsetninger (Simonsen 1972). Helleren hadde et svakt overheng dannet av flere blokksteiner. Det undersøkte arealet var på ca. $15 \mathrm{~m}^{2}$, og det ble gravd $50 \mathrm{~cm}$ dypt. Inntil fjellfoten ble det påvist et ildsted, ca. $40 \mathrm{~cm}$ under overflaten (Bang-Andersen 1971). Funnene fra helleren består av en hel del flintartefakter (Bergsvik og Storvik 2012:32), men den største funngruppen er keramikk, og til sammen ble det funnet over 2000 skår. De er ikke datert typologisk, og de lå spredt innenfor store deler av det undersøkte området. Ildstedet er C14-datert til 50 f.Kr. - 140 e.Kr. (T-1202, $1950 \pm 80 \mathrm{BP})$.

\section{Dognesteinen på Vatnamotholmane i Hå kommune}

Dognesteinen er en heller som lå på Vatnamotholmane ved Ogna, helt sør i Hå kommune (figur 1). I likhet med kystlandskapet lenger sør i Rogaland, er det mye bart fjell og begrensede arealer med løsmasser i området. Helleren ble undersøkt i 1931, og var dannet av tre store steiner. Den lå ca. $25 \mathrm{~m}$ over havet og rundt $150 \mathrm{~m}$ fra sjøen (Kloster 1931). I helleren ble det påvist et ca. $30 \mathrm{~m}^{2}$ stort og $80 \mathrm{~cm}$ tykt kulturlag. Om lag $10 \mathrm{~m}^{2}$ av laget ble undersøkt. Nær dråpefallet, og forholdsvis høyt i kulturlaget ble det funnet et ildsted. I samme område fantes det også et lag med skjell like under torva. Funnmaterialet fra Dognesteinen er variert og viser at helleren ble benyttet i flere forhistoriske perioder (Storvik 2011). I hele kulturlaget var det en god del bein av bl.a. hjort, sel, svin, sau/geit og torsk (Kloster 1931), og en tann av sau/geit er datert til 385-190 f.Kr. (Tua-2857, 2230 75 BP).

\section{Røyneberg i Sola kommune}

I 1996 ble en liten heller ved Moseid på Røyneberg i Sola kommune (figur 1) nærmere undersøkt (Larsen og Hemdorff 1996). Helleren var ca. $7 \mathrm{~m}$ lang og hadde et forholdsvis bratt overheng som har begrenset arealet innenfor dråpefallet. Den lå ca. $15 \mathrm{~m}$ over havet $\mathrm{i}$ et småkupert område og forholdvis nær det som har vært den nordlige bredden til det $4,5 \mathrm{~km}^{2}$ 
store Stokkavatnet. Dette vannet ble drenert ut på begynnelsen av 1900-tallet (BangAndersen 1986). Til sammen ble $5 \mathrm{~m}^{2}$ av arealet under helleren undersøkt i plan, og det ble gravd $30 \mathrm{~cm}$ dypt. Om lag $25 \mathrm{~cm}$ under overflaten ble det påvist et ildsted, som er C14-datert

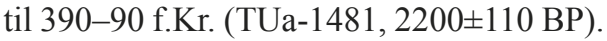

\section{Barka i Strand kommune}

Helleren på Barka i Strand kommune (figur 1) ble undersøkt i 2009 (Eilertsen 2010a, 2010b). Den var dannet av to store steinblokker ved foten av en bratt skråning, og lå ca. 34 $\mathrm{m}$ over havet. Til sammen ble $17 \mathrm{~m}^{2}$ undersøkt i plan, og på det meste ble det gravd ned til ca. $80 \mathrm{~cm}$ under overflaten. Under og like utenfor dråpefallet ble det påvist 12 kokegroper og ildsteder. De lå i ulik dybde, men de fleste kan relateres til nivåer rundt $40 \mathrm{~cm}$ under overflaten. Fire av kokegropene og to av ildstedene er C14-datert. Et av ildstedene og den ene kokegropen er datert til yngre bronsealder, mens de resterende er datert til førromersk jernalder og tidlig romertid (tabell 2).

\section{Fosnaneset $i$ Karmøy kommune}

I 2005 ble det undersøkt en heller innerst i Vollsvika på gården Fosnaneset på Fosenhalvøya i Karmøy kommune (figur 1). Den lå i et daldrag som strekker seg sørover fra sjøen. Landskapet i området er skrint og preget av fjellknauser. Helleren hadde et overheng på nær $5 \mathrm{~m}$, mens arealet innenfor dråpefallet var på rundt $7 \mathrm{~m}^{2}$ (Olsen 2006, Skjelstad og Midtbø 2011). Helleren lå 17-19 m over havet og om lag $100 \mathrm{~m}$ fra sjøen. Til sammen ble det undersøkt 25 $\mathrm{m}^{2}$ i plan og opp mot $1 \mathrm{~m}$ på det dypeste. Under og like utenfor helleren ble det påvist åtte ildsteder og en udefinert nedgravning. To av ildstedene er datert til førromersk jernalder

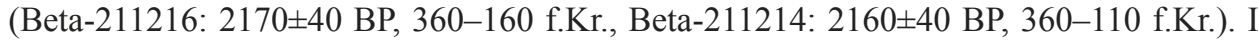
tillegg er et brent korn, trolig bygg (Hordeum), datert til samme periode (TUa-6110: 2345 \pm 30 BP, 480-380 f.Kr.). De andre daterte ildstedene kan knyttes til opphold i yngre bronsealder og eldre romertid (Skjelstad og Midtbø 2011:134). Nær halvparten av funnene fra helleren bestod av keramikkskår som kan relateres til aktiviteten i bronsealder og eldre jernalder (Skjelstad og Midtbø 2011:125-127).

Tabell 2. C14-daterte strukturer og lag fra undersøkelsen på Barka.

\begin{tabular}{|l|l|l|l|l|}
\hline Kontekst & Datert materiale & Lab.-ID & Datering før nåtid (BP) & $\begin{array}{l}\text { Kalibret alder (68\% } \\
\text { sannsynlighet) }\end{array}$ \\
\hline VP2 - A2 kokegrop & Bjørk (Betula) & TRa-614 & $2150+30$ & $195-125$ f.Kr. \\
\hline VP5 - A6 kokegrop & Hassel (Corylus) & TRa-615 & $2150+30$ & $195-120$ f.Kr. \\
\hline VP7 - A7 kokegrop & Or (Alnus sp.) & TRa-616 & $2475+30$ & $765-515$ f.Kr. \\
\hline VP8 - A8 ildsted & Or (Alnus sp.) & TRa-617 & $2270+30$ & $385-255$ f.Kr. \\
\hline VP11 - A11 ildsted & Or/Bjørk (Alnus sp./Betula) & TRa-618 & $2785+30$ & $930-895$ f.Kr. \\
\hline VP14 - kokegrop & Løvtre & TRa-619 & $1965+30$ & $15-80$ e.Kr. \\
\hline VP15 - bunn av lag M4 & Or (Alnus sp.) & TRa-620 & $3290+30$ & $1605-1515$ f.Kr. \\
\hline
\end{tabular}




\section{Haugsnes i Tysvaer kommune}

Helleren på Haugsnes, sør i Tysvær kommune (figur 1), ble undersøkt i 1987 (Gjerland 1990). Den lå ca. $220 \mathrm{~m}$ fra sjøen og $19 \mathrm{~m}$ over havet. I dråpefallet var høyden $3 \mathrm{~m}$, mens arealet innenfor hellertaket var på ca. $35 \mathrm{~m}^{2}$. Til sammen ble $23 \mathrm{~m}^{2}$ undersøkt i plan, og på det meste ble det gravd ca. $80 \mathrm{~cm}$ dypt. Det ble påvist to ildsteder, som lå henholdsvis $30 \mathrm{~cm}$ og $50 \mathrm{~cm}$ under overflaten. Funnmaterialet fra helleren var sparsomt, men steinartefaktene antyder bruk i tidlig- og seinneolitikum (Gjerland 1990:29). Det fantes også enkelte brente bein, bl.a. av hjort og sau/geit, samt en del keramikkskår. Flertallet av keramikkskårene kan dateres typologisk til førromersk jernalder, og de lå hovedsakelig i den ytre delen av helle-

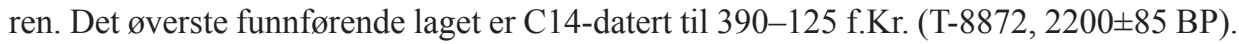

\section{Hellerne og gårdsbosetningen i førromersk jernalder}

Vegetasjonshistoriske studier viser at det fant sted en gradvis avskoging av rogalandskysten fra slutten av seinneolitikum (ca. 2000 f.Kr.) og fremover, og det resulterte i etableringen av lynghei (Prøsch-Danielsen og Simonsen 2000). På Jæren dominerte lyngheia allerede i yngre bronsealder (900-700 f.Kr.), mens den kom noe senere (ca. 200 f.Kr.) i Nord- og SørRogaland (Prøsch-Danielsen og Simonsen 2000:37-40). Denne utviklingen henger nøye sammen med ekspansjonen og endringene i bosetningsmønsteret, særlige fra yngre bronsealder og fremover (Myhre 2002:78-79). I tillegg har også økt fokus på fehold og beiteressurser vært viktig for fremveksten og vedlikeholdet av lyngheilandskapet (Kaland 1979; Prøsch-Danielsen og Simonsen 2000). Hellerne i Rogaland har vært en del av dette landskapet i førromersk jernalder, og pollenanalyser viser at det ble beitet i nærheten av dem, både på Fosnaneset, på Haugsnes og i Gjeldestadvika (Simonsen 1972, Eide og Paus 1982; Midtbø 2011). Selv i de karrige heiområdene øst for Jøssingfjord er det påvist spor etter svirydding og beite i perioden (Høeg 1999:189).

Det arkeologiske materialet viser at flere av hellerne har vært lokalisert forholdsvis nær den samtidige gårdsbosetningen. For eksempel ligger helleren på Barka kun ca. $150 \mathrm{~m}$ fra et boplassområde med spor etter flere hus fra eldre og yngre jernalder (Hemdorff 1985). Husene lå på en godt drenert og sørvendt flate ned mot sjøen, mens helleren fantes i grensa mellom de lettdyrkede arealene og de bratte fjellsidene i nord. Tilsvarende ser en også på Røyneberg. Her var helleren lokalisert i ulendt terreng ned mot Stokkavatnet, mens den samtidige gårdsbosetningen lå på et sørvendt høydedrag 700-800 m unna (Hulth 1997). I Gjeldestadvika er det registrert en rekke spor etter både hus og dyrking fra bronsealder og jernalder (Bjørdal og Dugstad 2014), og i førromersk jernalder lå gårdsbosetningen og åkrene på et godt drenert høydedrag om lag 300 m vest for helleren (figur 7).

De andre hellerne kan ikke i samme grad relateres til en gårdsbosetning. Landskapet tilsier også at det har vært større avstand mellom dem og de samtidige gårdene. Ved Fosnaneset er det utført omfattende arkeologiske og vegetasjonshistoriske undersøkelser, men det er ingen trekk i materialet som indikerer at det var en førromersk gårdsbosetning i umiddelbar nærhet av helleren (Skjelstad 2011a:245-246). De mest gunstige stedene for jordbruk på Fosenhalvøya ligger imidlertid kun $2 \mathrm{~km}$ fra helleren, og flere gravminner tyder på at det fantes en gårdsbosetning her allerede i eldre jernalder (Skjelstad 2011b:65). Arkeologiske og naturvitenskapelige undersøkelser i områdene rundt Haugsnes gir et lignende bilde (Eide og Paus 1982; Gjerland 1990), der den nærmeste registrerte gårdsbosetningen 


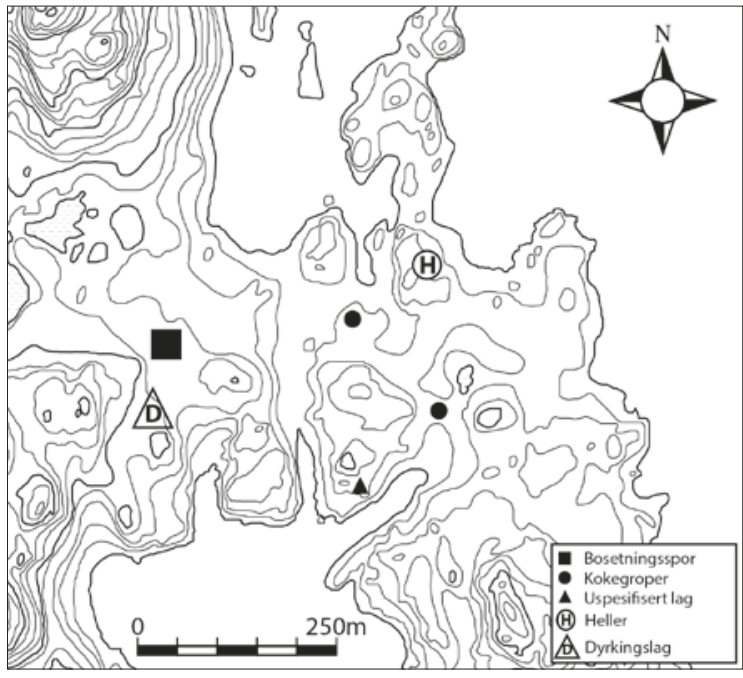

Figur 7. Relasjonen mellom helleren og bosetningssporene $i$ Gjeldestadvika på Eigerøy, Eigersund kommune. Illustrasjon: Trond Meling.

fra eldre jernalder ligger om lag $3 \mathrm{~km}$ vest for helleren (Midthjell 2010). Det kuperte landskapet ved Vatnamotholmane fremstår ikke som et utpreget jordbruksområde, og sannsynligvis må en til Ogna $i$ nord og Hellvik i sør for å finne samtidige gårder. Begge disse områdene, som ligger 3-4 km fra Vatnamotholmane, fremstår som gode jordbruksområder, med en rekke bosetningsspor fra flere perioder (Haavaldsen 1995; Skjølsvold 1970a, 1970b). Det er ikke utført arkeologiske undersøkelser i nærområdene til Jøssingfjord, men også her tilsier terrengforholdene at det ikke har vært noen gårdsbosetning ved Helleren. Mest trolig er Hauge, som ligger ca. $3 \mathrm{~km}$ nordvest for fjorden, og som er rik på kulturminner (Haraldsen 1982), det nærmeste stedet hvor en kan forvente å finne gårder fra perioden.

Avstanden mellom hellerne og påvist/antatt gårdsbosetning i førromersk jernalder varierer noe. Det er imidlertid ingen som ligger mer enn ca. $3 \mathrm{~km}$ unna gunstige jordbruksområder. En slik lokalisering av hellerne er ikke uvanlig (Bakka 1973), og forholdene i Rogaland samsvarer godt med det en ser i Hordaland (Østebø 2008:47-48).

\section{Hellerne og det kollektive landskapet i førromersk jernalder}

I Rogaland er den førromerske aktiviteten i hellerne først og fremst belagt gjennom daterte ildsteder og kokegroper. I noen, bl.a. på Haugsnes og på Fosnaneset, er det også funnet keramikk som kan relateres til perioden, men ellers er gjenstandsmaterialet forholdvis begrenset. Unntaket er helleren i Gjeldestadvika, hvor det fantes store mengder keramikk. Det er imidlertid usikkert om den er fra samme tid som det daterte ildstedet. Faunamaterialet er også svært beskjedent, og det er kun fra hellerne i Jøssingfjord og ved Vatnamotholmane deler av det er datert til perioden. Helleren i Jøssingfjord er for øvrig den eneste hvor det er påvist en tydelig akkumulasjon av kulturlag i førromersk jernalder. Selv om bevaringsforholdene ikke har vært like gunstige i alle hellerne, gir det arkeologiske materialet inntrykk av at de fleste ble benyttet sporadisk og i forholdvis korte perioder av gangen. Det er også verdt å påpeke at flere av hellerne, bl.a. de på Røyneberg, Barka og i Gjeldestadvika, har vært relativt små, og det må ha satt klare begrensninger for både bruken og lengden på oppholdene.

Helleren i Jøssingfjord skiller seg klart ut i materialet fra Rogaland. For det første er den langt større og mer dominerende i landskapet enn de andre hellerne. I tillegg har den vært forholdvis vanskelig tilgjengelig fra land, siden den ligger i et trangt og ugjestmildt område 
omkranset av bratte fjellsider. De arkeologiske undersøkelsene i Helleren har et begrenset omfang, men faunamaterialet indikerer at aktivitetene har vært rettet mot fiske, jakt på sjøpattedyr og sanking av skjell. Dateringene av og tykkelsen til kulturlaget tyder også på at bruken var relativt omfattende i førromersk jernalder. Dette står i sterk kontrast til de andre hellerne i Rogaland. Den utstrakte bruken i førromersk jernalder skiller seg også fra flere undersøkte hellere i Sunnhordland, hvor de mest intensive bruksperiodene har vært i romertid og folkevandringstid (Bommen 2009:73, 87). I hellermaterialet fra Hordaland er det påvist en langt større artsvariasjon i beinmaterialet, både fra førromersk jernalder og fra senere perioder, enn den vi ser i Helleren (Bommen 2009:74; Hufthammer 2015). I noen, bl.a. Setrehelleren på Bømlo og Kuhidlaren på Huglo, utgjør bein av sjøpattedyr og fisk en forholdsvis stor andel av den totale mengden (Bommen 2009), men generelt er det hjortedyr som dominerer i lagene fra førromersk jernalder (Hufthammer 2015:236).

Siden det osteologiske materialet fra Helleren er begrenset og ikke analysert i detalj, er det vanskelig å vurdere varigheten av oppholdene og om bruken kan knyttes til bestemte tider av året. Det sparsomme arkeologiske materialet gir heller ingen gode holdepunkter for å vurdere oppholdene i detalj, men de få gjenstandsfunnene fra Helleren kan tyde på at bruksperiodene har vært forholdvis kortvarige. Fokuset på marine ressurser kan ha sammenheng med ressurstilgangen i området, men uansett om det er tilfelle eller ikke, viser den marine vektleggingen at formålet med besøkene har vært spesifikke og målrettede. Fordelingen av skjell og bein i kulturlaget antyder også at den har vært uforandret gjennom hele perioden. En mulig forklaring kan være at Helleren var en spesialisert boplass for en befolkning som hadde et sterkt fokus på jakt og fangst, slik Knut Andreas Bergsvik (2006) har foreslått for enkelte små boplasser langs vestlandskysten. I så fall må Helleren ha vært en av flere mer eller mindre spesialiserte boplasser som ble benyttet på sesongmessig basis. Det tykke kulturlaget og den omfattende utnyttelsen av Helleren gir imidlertid inntrykk av at oppholdene og bruken har innbefattet flere personer enn et hushold eller en familiegruppe. Den ensidige marine ressursutnyttelsen taler også for at aktivitetene har vært godt organisert. En annen forklaring kan derfor være at bruken av helleren og arbeidet med a høste ressursene fra havet har vært en kollektiv oppgave der utvalgte medlemmer fra flere hushold/familiegrupper var involvert. På samme måte som etableringen av gårder og fordelingen av jord trolig var sanksjonert gjennom felles beslutninger i denne perioden (Gerritsen 1999:146; Herschend 2009:169-170), kan aktivitetene i Helleren ha vært underlagt tilsvarende bestemmelser og normer fra samfunnet. Bestemmelsene kan ha regulert hvem og hvor mange som tok del i arbeidet, og når på året helleren ble benyttet. Håndhevingen av reglene kan ha blitt ytterligere forsterket gjennom de mektige dimensjonene til Helleren og lokaliseringen i landskapet, særlig med tanke på at den har hatt en begrenset tilgjengelighet.

Det arkeologiske materialet fra de andre hellerne gir også begrenset informasjon om aktivitetene knyttet til dem. I samtlige er det imidlertid funnet ett eller flere ildsteder/kokegroper. En rekke steder, både i lavlandet og i fjellet, har en påvist tilsvarende enkeltliggende eller små samlinger med kokegroper datert til denne perioden (Meling 2008; Prescott 1995, 1999). I fjellet fremstår gropene som isolerte, uten relasjon til bygninger eller andre strukturer (Prescott 1995:140, 1999:218-219), mens de som regel er lokalisert forholdsvis nær de samtidige gårdene i lavlandet (Meling 2008:603-604). Et eksempel på det er Gjeldestadvika, hvor det er funnet flere kokegroper på tørre flater og forhøyninger mellom helleren og gårdsbosetningen (figur 7). Felles for gropene i fjellet og i lavlandet er at de ligger i beite- 
landskap (Meling 2008:604; Prescott 1999:218-219). I Östergötland i Sverige er det også eksempler på at enkeltliggende kokegroper og samlinger av dem har ligget nær samtidige åkrer et stykke unna gårdene (Petersson 2001:135-136, 2006:167-169).

De mange spredtliggende kokegropene vitner om en utstrakt bruk av landskapet og ressursene som fantes i utmarka i førromersk jernalder. Sannsynligvis er det i denne sammenheng en skal se de mer sporadiske aktivitetene $i$ enkelte hellere i denne perioden. Bruken faller også sammen med utviklingen av lyngheilandskapet i Rogaland, og som nevnt er det påvist spor etter beite ved flere av hellerne. I likhet med kokegroplokalitetene kan de ha fungert som rasteplasser for gjetere eller som steder hvor beitedyrene ble samlet for stell, melking og lignende (jf. Petersson 2001:140-141, 2006:168-169; Prescott 1999:218). De som har ligget lengst unna gårdsbosetningen, kan ha tjent som overnattingssteder i perioder, og vi skal ikke se bort fra at enkelte har fungert som en form for seter, slik Egil Bakka (1973:111-112) foreslo. Et regulært setersystem, slik vi kjenner det fra historisk tid, har det sannsynligvis ikke vært i denne perioden (Myhre 2002:90-91), men det er grunn til å tro at beiteaktivitetene var godt organisert (Petersson 2004:231-232). Flere har pekt på at den sterke bosetningsekspansjonen i førromersk jernalder trolig førte til at områdene utenfor gårdene og innmarka også var underlagt visse kollektive reguleringer (Björhem og Staaf 2006:192; Friman 2008:116; Holst 2010:158-159). Disse reguleringene kan bl.a. ha innbefattet rettigheter til å utnytte den gårdsnære utmarka til beite. Etableringen av fjøs i langhusene indikerer at husholdene og familiegruppene fikk større råderett over dyrene (Løken 1998:120; Myhre 2002:111; Olausson 1999). Dette igjen kan ha ført til økt behov for å markere bruks- og beiteretter i landskapet (Meling 2008:606). Siden hellerne ligger i beitelandskap og forholdsvis nær samtidige gårder og jordbruksområder, er det rimelig å tro at de kan ha vært viktige element i en slik regulering. Hellerne fremstår ofte som karakteristiske terrengformasjoner, og kan dermed ha fungert som viktige referansepunkt i organiseringen og utøvelsen av beiteretter. På samme måte som enkelte graver og gravfelt har fungert som grenser for større bosetningsområder i denne perioden (Herschend 2009:118), kan hellerne, særlig de som har ligget et stykke fra gårdsbosetningen, ha tjent som grensemarkeringer og ytterpunkter innenfor et større, kollektivt beitelandskap.

Dateringene fra Helleren antyder at aktivitetene opphørte mot slutten av førromersk jernalder, og at de ikke ble tatt opp igjen før ved overgangen til merovingertid. Hellerne på Barka og Fosnaneset, som er de eneste i denne studien hvor det er definert flere bruksfaser gjennom C14-dateringer, viser et lignende bilde ved at de yngste fasene er fra eldre romertid. Bruken av hellere tok på ingen måte slutt ved overgangen til romertid eller i løpet av denne perioden. Tvert imot blir yngre romertid og folkevandringstiden sett på som de mest intensive bruksfasene i Sør-Norge (Jansen 1973:103; Myhre 2002:119; Odner 1973:147). I mange hellere ser en også et mer mangfoldig arkeologisk og osteologisk materiale fra tiden etter Kristi fødsel, og det ser ut til at bruken ble mer variert enn tidligere (bl.a. Bommen 2009:80-81; Jansen 1973:102-103). I løpet av romertiden fikk gårdene en permanent karakter med et tydeligere skille mellom innmark og utmark (Myhre 2002:143-145). Frands Herschend (2009:141) karakteriserer denne endringen som overgangen fra et flytende til et fast landskap. De førromerske gårdene, som stadig måtte «reetableres» i landskapet, ble erstattet av en mer stabil gårdsstruktur der felles løsninger kom mer i bakgrunnen. Disse endringene har sannsynligvis fått konsekvenser for hvordan ressursene i den gårdsnære utmarka ble utnyttet og forvaltet, og det kan være årsaken til at enkelte hellere gikk ut av 
bruk i slutten av førromersk jernalder og tidlig romertid. Behovene for å markere rettigheter i beitelandskapet kan ha endret seg eller blitt praktisert på andre måter, og flere hellere kan ha mistet sin funksjon som referansepunkt siden lokaliseringene ikke hadde samme betydning som tidligere. På samme måte kan grunnlaget for en felles utnyttelse av utmarksressursene, som vi ser tegn på i Helleren, ha blitt erstattet av en mer individuell bruk knyttet til de enkelte gårdene. En slik utvikling kan være en forklaring på hvorfor hellerbruken intensiveres og blir mer mangfoldig i tiden etter vår tidsregnings begynnelse.

\section{Summary \\ Rock shelters and landscape use in Rogaland during the Pre-Roman Iron Age}

This article discusses the occupation of rock shelters in Rogaland during the Pre-Roman Iron Age (BC 500-1). In total, seven rock shelters show traces of use in this period, and all are located less than $3 \mathrm{~km}$ from contemporary farms or good farming areas. In South-Norway, the settlement expanded substantially during this period. A reason for this was a collective approach concerning how and where to settle. The expansion led to a greater pressure on outfield resources and grazing areas. The location of rock shelters suggests that they served as important focal points in the landscape when organizing and exercising rights to exploit outfield resources. The occupation in most of the rock shelters seems to have been sporadic and for short periods only, and most likely the rock shelters have served as nodes when organizing grazing activity. One rock shelter stands out with thick cultural layers and traces of a specialized utilization of maritime resources. This kind of specialized work and repeated visits over a long period suggests a collective use and the collaboration of different farms and households.

\section{Litteratur}

Bakka, Egil

1973 Omkring problemet om kulturdualisme i Sør-Noreg. I Bonde-veidemann, bofast-ikke bofast $i$ nordisk forhistorie, redigert av Povl Simonsen og Gerd Stamsø Munch, s. 109-127. Tromsø Museums Skrifter, vol. XIV. Universitetsforlaget, Tromsø.

Bang-Andersen, Sveinung

1971 Notat angående funnmaterialet fra undersøkelsen av R22 i Gjeldestadvika, Eigersund kommune. Topografisk arkiv, Arkeologisk museum, Universitetet i Stavanger.

1986 De mange sjøers land - et bidrag til Jærens landskapshistorie. Stavanger Museums årbok 95:55-68.

Bergsvik, Knut Andreas

2005 Kulturdualisme i vestnorsk jernalder. I Fra funn til samfunn. Jernalderstudier tilegnet Bergljot Solberg på 70-årsdagen, redigert av Knut Andreas Bergsvik og Asbjørn Engevik, s. 229-258. Universitetet i Bergen Arkeologiske Skrifter 1. Universitetet i Bergen, Bergen.

2006 Førromersk jernalder ved Skatestraumen - sosiale og økonomiske implikasjoner. Viking 69:107-130.

Bergsvik, Knut Andreas og Ingebjørg Storvik

2012 Mesolithic Caves and Rockshelters in Western Norway. I Caves in Context. The Cultural Significance of Caves and Rockshelters in Europe, redigert av Knut Andreas Bergsvik og Robin Skeats, s. 22-38. Oxbow Books, Oxford.

Bjørdal, Even og Sigrid Alræk Dugstad

2014 Kulturhistoriske registreringer. Aker Solutions - Eigerøy gnr. 8, bnr. 36, Eigersund kommune. Rogaland fylkeskommune Rapport 3/2014. Topografisk arkiv, Arkeologisk museum, Stavanger. 
Björhem, Nils og Björn Magnusson Staaf

2006 Långhuslandskapet. En studie av bebyggelse och samhälle från stenålder till järnålder.

Öresundforbindelsen och arkeologin. Malmöfynd nr 8. Malmö kulturmiljö, Malmö.

Bommen, Camilla E.

2009 Bruken av hellerar i eldre jernalder i Sunnhordland. Upublisert masteroppgåve i arkeologi. Institutt for arkeologi, historie, kultur- og religionsvitenskap, Universitetet i Bergen, Bergen.

Brøgger, Anton Wilhelm

1925 Det norske folk i oldtiden. Instituttet for sammenlignende kulturforskning, Serie A: Forelesninger VIa. Aschehoug, Oslo.

Bukkemoen, Grethe Bjørkan

2015 Ett hus - mange livsløp. Boligens biografi i førromersk jernalder belyst gjennom et gårdsanlegg i Askim. Viking 78:95-118.

Dahl, Jean Sømme

1982 Sokndals geologi. Fra haug ok heiðni 1982(2):27-29.

Diinhoff, Søren

1999 Trækk af det Vestlandske jordbrugs historie fra sen stenalder til tidlig middelalder. Arkeo 1:14-28.

2005a Den førromerske jordbruksbosætning på Moflaten ved Ørsta. I Fra funn til samfunn.

Jernalderstudier tilegnet Bergljot Solberg på 70-årsdagen, redigert av Knut Andreas Bergsvik og Asbjørn Engevik, s. 105-119. Universitetet i Bergen Arkeologiske Skrifter 1, Universitetet i Bergen, Bergen.

$2005 b$ Den vestnorske agrarbosætning. Fra sen stenalder til folkevandringstid. Arkeologiske resultater fra et tiår med fladeafdækninger på Vestlandet. I Konstrusksjonsspor og byggeskikk. Maskinell flateavdekking - metodikk, tolking og forvaltning, redigert av Mari Høgestøl, Lotte Selsing, Trond Løken, Arne Johan Nærøy og Lisbeth Prøsch-Danielsen, s. 75-85. AmS-Varia, vol. 43. Arkeologisk museum, Stavanger.

$2005 \mathrm{c}$ The issue of infield and outfield. I 'Utmark'. The Outfield as Industry and Ideology in the Iron Age and Middel Ages, redigert av Ingunn Holm, Sonja Innselset og Ingvild Øye, s. 109-118. UBAS International 1. Universitetet i Bergen, Bergen.

Dommasnes, Liv Helga

1997 Tradisjon og handling i førkristen vestnorsk gravskikk. I. Undersøkelser på et gravfelt på Vereide $i$ Gloppen, Sogn og Fjordane. Arkeologiske rapporter 21. Arkeologisk institutt, Universitet i Bergen, Bergen.

2001 Tradisjon og handling i førkristen vestnorsk gravskikk. II. Fra Vereide til vikingtid. Arkeologiske avhandlinger og rapporter fra Universitetet i Bergen 5. Arkeologisk institutt, Universitetet i Bergen, Bergen.

2006 Vestnorsk forhistorie, et personlig perspektiv. Vigmostad \& Bjørke, Bergen.

Eide, Frøydis Gramstad og Aage Paus

1982 Vegetasjonshistoriske undersøkelser på Kårstø, Tysvcer kommune, Rogaland. Botanisk institutt Rapport 23. Universitetet i Bergen, Bergen.

Eilertsen, Krister Scheie

2010a Arkeologiske undersøkelser av heller på Barka, Bjørkhaug 42/3, Strand kommune. Oppdragsrapport B 2010/5, Arkeologisk museum, Universitetet i Stavanger.

2010b Helleren på Barka i Strand - oppholdssted og naturformasjon i årtusner. Fra haug ok heiðni 2010(1):3-10.

Friman, Bo

2008 Att stå på egna ben. Centrala funktioner och lokal utveckling under yngre bronsålder och äldre järnålder i Mellanbyn, Skåne. Malmöfynd nr 18. Malmö Kulturmiljö, Malmö.

Gerritsen, Fokke

1999 The cultural biography of Iron Age houses and long-term transformation of settlement patterns in southern Netherlands. I Settlement and Landscape. Proceeding of a conference in Arrhus, May 4-7 1998, Denmark, redigert av Charlotte Fabech og Jytte Ringtvedt, s. 139-148. Jutland Archaeological Society, Højbjerg. 
Gjerland, Berit

1990 Arkeologisk undersøkingar på Haugsnes og Ognøy i Tysvaer og Bokn kommunar, Rogaland.

AmS-Rapport, vol. 5. Arkeologisk museum, Stavanger.

Gjessing, Gutorm

1945 Norges steinalder. Norsk Arkeologisk Selskap, Oslo.

Grønnesby, Geir

1999 Et eldre jernalders hus og hall på Hovde i Trøndelag. Viking 62:69-80.

Hagen, Anders

1967 Norges oldtid. J. W. Cappelens forlag, Oslo.

Hansteen, Hans Jacob

2014 Helleren i Jøssingfjord og andre boliger. Arbok for Dalane 2013-2014:11-48.

Haraldsen, Tom $\mathrm{H}$.

1982 Mennesker og miljø i Sokndal fra steinalder til vikingtid. Fra haug ok heiðni 1982(2):34-41.

Hemdorff, Olle

1985 Barkavika - boplads fra ældre og yngre jernalder. Fra haug ok heiðni 1985(3):258-260.

Herschend, Frands

2009 The Early Iron Age in South Scandinavia. Social Order in Settlement and Landscape. Occasional Papers in Archaeology, vol. 46. Uppsala Universitet, Uppsala.

Holst, Mads Kähler

2010 Inconstancy and stability - Large and small farmsteads in the village of Nørre Snede (Central Jutland) in the first millennium AD. I Settlement and Coastal Research in the Southern North Sea Region 33, redigert av Niedersächsisches Institut für historische Küstenforschung, Wilhelmshaven, s. 155-179. Verlag Marie Leidorf GmbH, Rahden.

Hufthammer, Anne Karin

2015 Osteological assemblages from rock shelters as source data for subsistence from Bronze Age to the Middle Ages in Western Norway. I Exploitation of outfield resources - Joint Research at the University Museums of Norway, redigert av Svein Indrelid, Kari Loe Hjelle og Kathrine Stene, s. 231-240. Universitetsmuseet i Bergen skrifter nr. 32. Universitetet i Bergn, Bergen.

Hulth, Helena

1997 Jåttå och Røyneberg - förhistoriska boplatser längs nya huvudvattenledningen. Fra haug ok heiðni 1997(4):21-27.

Høeg, Helge Irgens

1999 Pollenanalytiske undersøkelser i Rogaland og Ersdal i Vest-Agder. I Museumslandskap. Artikkelsamling til Kerstin Griffin på 60-årsdagen, redigert av Lotte Selsing og Grete Lillehammer, s. 145-225. AmS-Rapport, vol. 12A. Arkeologisk museum, Stavanger.

Haavaldsen, Per

1995 Fra bronse til jern. Glimt av funn og fornminner fra bronsealder og jernalder i Eigersund. Fra haug ok heiðni 1995(3):10-17.

Jansen, Kristian

1973 De vestnorske hulefunn og problemet omkring jeger-fisker-bonde. I Bonde-veidemann, bofastikke bofast i nordisk forhistorie, redigert av Povl Simonsen og Gerd Stamsø Munch, s. 100-109. Tromsø Museums Skrifter, vol. XIV. Universitetsforlaget, Tromsø.

Kaland, Peter Emil

1979 Landskapsutvikling og bosetningshistorie i Nordhordlands lynghei-område. I På leiting etter den eldste garden. Nye metoder $i$ studie av tidlig norsk bosettingshistorie, redigert av Rolf Fladby og Jørn Sandnes, s. 41-70. Universitetsforlaget, Oslo.

Kloster, Robert

1931 Innberetning om utgraving av boplass fra steinalderen ved gården Tuen i Ogna sokn, Egersund prestegjeld. Upublisert innberetning i topografisk arkiv. Arkeologisk museum, Universitetet i Stavanger, Stavanger.

Larsen, Ingvild og Olle Hemdorff

1996 IVAR, ny hovedvannledning fra Langvatn, Gjesdal kommune til Tjensvoll, Stavanger kommune. Upublisert innberetning i topografisk arkiv. Arkeologisk museum, Universitetet i Stavanger, Stavanger. 
Løken, Trond

1998 Hustyper og sosialstruktur gjennom bronsealder på Forsandmoen, Rogaland, Sørvest-Norge.

I Bronsealder i Norden. Foredrag ved det 7. nordiske bronsealdersymposium i Rogaland 31. august-3. september 1995, redigert av Trond Løken, s. 107-121. AmS-Varia, vol. 33.

Arkeologisk museum, Stavanger.

2001 Oppkomsten av den germanske hallen - Hall og sal i eldre jernalder i Rogaland. Viking 64:49-86.

Løken, Trond, Lars Pilø og Olle Hemdorff

1996 Maskinell flateavdekking og utgraving av forhistoriske jordbruksboplasser, en metodisk innføring. AmS-Varia, vol. 26. Arkeologisk museum i Stavanger, Stavanger.

Meling, Trond

2008 Jernalder-Middelalder 500 BC-1536 AD. I Ormen Lange Nyhamna. NTNU-Vitenskapsmuseets arkeologiske undersøkelser, redigert av Hein B. Bjerck, s. 601-608. Tapir Akademisk Forlag, Trondheim

2016a Arkeologiske sikringsgranskingar i Helleren (id 34551). Haneberg gnr. 46, bnr. 82 i Sokndal kommune. Oppdragsrapport 2016/22. Arkeologisk museum, Universitetet i Stavanger, Stavanger.

2016b Arkeologiske granskingar av busetjingsspor frå yngre jernalder i Helleren (id 34551). Haneberg gnr. 46, bnr. 82 i Sokndal kommune. Oppdragsrapport 2016/19. Arkeologisk museum,

Midtbø, Inger Universitetet i Stavanger, Stavanger.

2011 Vegetasjonsutviklingen i Fosen-området. I Steinalderboplasser på Fosenhalvøya. Arkeologiske og naturvitenskaplige undersøkelser 2004-2007, T-forbindelsen, Karmøy kommune,

Nord-Rogaland, redigert av Guro Skjelstad, s. 55-59. AmS-Varia, vol. 52. Arkeologisk museum, Stavanger.

Midthjell, Harald

2010 Rapport fra kulturhistorisk registrering gnr. 54 Sandvig og gnr. 55 Susort, Tysvær kommune. Upublisert rapport i topografisk arkiv. Arkeologisk museum, Universitetet i Stavanger, Stavanger.

Myhre, Bjørn

1964a Innberetning om prøvegraving i en heller i Jøssingfjord 16/6 1964. Innberetning i topografisk arkiv. Arkeologisk museum, Universitetet i Stavanger, Stavanger.

1964b Et lovende funn fra en heller i Jøssingfjord. Fra haug ok heiðni 1964(3):55-57.

2002 Landbruk, landskap og samfunn 4000 f.Kr.-800 e.Kr. I Norges landbrukshistorie I, redigert av

Odner, Knut Bjørn Myhre og Ingvild Øye, s. 12-213. Samlaget, Oslo.

1973 Økonomiske strukturer på Vestlandet i eldre jernalder. Upublisert manuskript. Bergen.

Olausson, Michael

1999 Herding and stalling in Bronze Age Sweden. I Settlement and Landscape. Proceeding of a conference in Arhus, Denmark, May 4-7 1998, redigert av Charlotte Fabech og Jytte Ringtvedt, s. 319-328. Jutland Archaeological Society, Højbjerg.

Olsen, Thomas Bruen

2006 Et lite, men lunt oppholdssted i 6000 år. Fra haug ok heiðni 2006(1):26-34.

Petersson, Maria

2001 Grazing and hearts in west Östergötland 1000-1 BC. I One Land, Many Landscapes. Papers from a session held at the European Association of Archaeologists Fifth Annual Meeting in

Bournemouth 1999, redigert av Timothy Darvill og Martin Gojda, s. 125-145. BAR International Series 987. Archaeopress, Oxford.

2004 Animal husbandry and social hierarchies in Östergötland in the Pre Roman Iron Age. I PECUS. Man and Animal in Antiquity. Proceedings of the Conference at the Swedish Institute in Rome, September 9-12, 2002, redigert av Barbro Santillo Frizell, s. 225-234. The Swedish Institute in Rome. Projects and Seminars 1, Rome.

2006 Djurhållning och betesdrift. Djur, människor och landskap i Västra Östergötland under yngre bronsålder och äldre järnålder. Riksantkvarieämbetet, Stockholm. 
Pilø, Lars

1989 Den førromerske jernalder i Vest-Norge. Et kulturhistorisk tolkningsforsøk. Upublisert

hovedfagsoppgave i arkeologi med vekt på Norden. Universitetet i Bergen, Bergen.

Prescott, Christopher

1995 From Stone Age to Iron Age. A Study from Sogn, western Norway. BAR International Series 603. Tempus Reparatum, Oxford.

1999 Long-term patterns of non-agrarian exploitation in southern Norwegian highlands. I Settlement and Landscape. Proceeding of a conference in Arhus, Denmark, May 4-7 1998, redigert av Charlotte Fabech og Jytte Ringtvedt, s. 213-223. Jutland Archaeological Society, Højbjerg.

Prøsch-Danielsen, Lisbeth og Asbjørn Simonsen

2000 The deforestation patterns and the establishment of the coastal heathland of southwestern Norway. AmS-Skrifter, vol. 15. Arkeologisk museum, Stavanger.

Rødsrud, Christian Løchsen

2008 Kontinuitet i en brytningstid? Samfunnsutviklingen under førromersk jernalder. I Facets of Archeology. Essays in Honour of Lotte Hedeager on her 60th Birthday, redigert av Konstantinos Chilidis, Julie Lund og Christopher Prescott, s. 397-408. Oslo Arkeologiske Serie, vol. 10. Institutt for arkeologi, konservering og historie, Universitetet i Oslo, Oslo.

Simonsen, Asbjørn

1972 Da bøndene kom til Gjedlestadvige. Fra haug ok heiðni 1972(2):235-240.

Skjelstad, Guro

2011a Fosenlokalitetene - oppsummering og diskusjon. I Steinalderboplasser på Fosenhalvøya. Arkeologiske og naturvitenskaplige undersøkelser 2004-2007, T-forbindelsen, Karmøy kommune, Nord-Rogaland, redigert av Guro Skjelstad, s. 217-246. AmS-Varia, vol. 52. Arkeologisk museum, Stavanger.

2011 b Arkeologiske undersøkelser - historikk. I Steinalderboplasser på Fosenhalvøya. Arkeologiske og naturvitenskaplige undersøkelser 2004-2007, T-forbindelsen, Karmøy kommune,

Nord-Rogaland, redigert av Guro Skjelstad, s. 65-72. AmS-Varia, vol. 52. Arkeologisk museum, Stavanger.

Skjelstad, Guro og Inger Midtbø

2011 Helleren lok. 2 - en heller i bruk gjennom 6000 år fra senmesolitikum til eldre romertid. I Steinalderboplasser på Fosenhalvøya. Arkeologiske og naturvitenskaplige undersøkelser 2004-2007, T-forbindelsen, Karmøy kommune, Nord-Rogaland, redigert av Guro Skjelstad, s. 116-136. AmS-Varia, vol. 52. Arkeologisk museum, Stavanger.

Skjølsvold, Arne

1970a En bronsealders boplass med hustuft fra Ogna i Rogaland. Viking 34:25-45.

1970b To keltertids hustufter fra Ogna i Rogaland. Viking 34:47-71.

Solberg, Bergljot

1976 Jernalderen på Nordre Sunnmøre. Bosetning, ressursutnyttelse og sosial struktur. Upublisert avhandling for magistergraden i nordisk arkeologi. Universitetet i Bergen, Bergen.

2000 Jernalderen i Norge. Ca. 500 f.Kr-1030 e.Kr. Cappelen Akademisk Forlag, Oslo.

Solevåg, Kristel

2002 Fra bronsealder til jernalder - en analyse med utgangspunkt i nordvestnorske bosetningsspor og gravfunn. Upublisert hovedfagsoppgave i arkeologi med vekt på Norden. Arkeologisk institutt, Universitetet i Bergen, Bergen.

Storvik, Ingeborg Njøs

2011 Bruken av huler og hellere i Rogaland. Fra steinalder til middelalder. Upublisert masteroppgave $\mathrm{i}$ arkeologi. Institutt for arkeologi, historie, kultur- og religionsvitenskap, Universitetet i Bergen, Bergen.

Østebø, Kjetil

2008 Hellerbruk i vestnorsk elder jernalder belyst ved lokalisering. Upublisert masteroppgave i arkeologi. Institutt for arkeologi, historie, kultur- og religionsvitenskap, Universitetet i Bergen, Bergen. 